\title{
Reproductive performance and growth response of the red alga Ceramium strictum under the impact of phenol
}

\author{
Britta Eklund* \\ ITM, Institute of Applied Environmental Research and Department of System Ecology, Stockholm University, \\ S-611 82 Nyköping, Sweden
}

\begin{abstract}
The toxic effect of phenol on 3 stages in the reproduction of the red alga Ceramium strictum was studied, i.e. the formation of reproductive organs, fertilisation capacity and maturation of cystocarps. Male and female gametophytes were exposed separately to different concentrations of phenol for $3 \mathrm{~d}$. Thereafter, experiments were conducted in which fertilisation and maturation of cystocarps were studied either with or without phenol present. The reproductive capacity was examined for all possible crossings of exposed and unexposed male and female gametophytes and the results were measured as the number of cystocarps produced. The development of reproductive organs on both female and male gametophytes was affected by phenol. The formation of female reproductive organs was about 20 times more sensitive than the reproductive functioning of the male spermatangium. Thus, a $50 \%$ reduction in reproductive capacity was estimated at around 5 to 7 and $100 \mathrm{mg}$ phenol $\mathrm{l}^{-1}$, respectively. The effect of phcnol on the fcmale gametophyte during fertilisation was decisive for the outcome of reproduction. The maturation of cystocarps was affected to a lesser extent. After fertilisation had taken place in phenol, a $20 \%$ decrease in reproductive capacity was observed when the maturation of cystocarps had taken place in phenol rather than in clean water. Thus, all 3 investigated phases were inhibited by phenol. The strongest and most permanent negative effect was seen on the reproductive organs of the female gametophyte. Marked changes in the morphological appearance of the female plants were noted when exposed for 3 different time periods, i.e. 1, 3 and $10 \mathrm{~d}$. At a concentration of $10 \mathrm{mg}$ phenol $\mathrm{l}^{-1}$ a loss of apical dominance was observed and instead of the normal dichotomous growth with very few branches, most cells initiated an extra lateral branch. This response was more pronounced at increasing phenol concentrations. A $24 \mathrm{~h}$ pulse exposure to phenol of more than $60 \mathrm{mg}$ $\mathrm{l}^{-1}$ influenced the growth pattern by as much as a week
\end{abstract}

KEY WORDS: Ceramium strictum - Red alga - Toxic - Phenol - Reproduction - Growth

\section{INTRODUCTION}

Ceramium strictum Harvey sensu Kylin is a 2 to $10 \mathrm{~cm}$ long marine red macroalga which grows epilithically or as an epiphyte from the water surface down to a depth of 20 to $25 \mathrm{~m}$. C. strictum belongs to the family Ceramiaceae, for which a thorough systematic study has yet to be carried out (J. Rueness pers comm., Maggs \& Hommersand 1993). The C. strictum species complex generally occurs in temperate regions of the world. In Sweden it is found on the west coast (i.e.

•E-mail: britta.eklund@itm.su.se
Skagerrak and Kattegat). C. strictum and other macroalgae constitute an important part of the coastal ecosystem as primary producers, biotope for organisms such as crustaceans and molluscs, substrate for fish spawn and nursery for fish. To fully understand the impact of a substance on an organism, all parts of its life cycle should be investigated. Many authors (e.g. Hopkin \& Kain 1978, Thursby et al. 1985, Andersson \& Kautsky 1996) have shown the reproductive and juvenile stages of an organism to be the most sensitive to toxic substances. In order to have a sustainable population the reproduction capacity must be high enough so that sufficient young individuals will survive to 
adulthood. Many stages are involved in the reproduction of $C$. strictum, such as the development of reproductive organs in both female and male gametophytes, the fertilisation process itself, and the quantity and maturation of the offspring.

The aim of this study was to determine the sensitivity of certain important stages in the life cycle of Ceramium strictum (Fig. 1). Phenol was used because it is a widely used reference substance for many biological assays (e.g. Anonymous 1992). The influence of different concentrations of phenol on the development of reproductive organs in male and female gametophytes, the fertilisation capacity, and the maturation of cystocarps was studied. In addition, the morphology and growth pattern of $C$. strictum female gametophytes were observed during growth in phenol for different lengths of time.

\section{METHODS}

The algal strain used in the experiments was originally isolated by Dr Jan Rueness at Oslo University and has been maintained in culture for more than $20 \mathrm{yr}$. It originates from the Oslo fjord, which has an average salinity of $20 \%$. Throughout this study, cultivation of the alga followed the protocol for the reproduction test using Ceramium strictum (Eklund 1995). This alga is practical to use in experiments due to the even, dichotomous growth of the female gametophyte (Figs. 1 \& 2). The male gametophyte has a bushier appearance

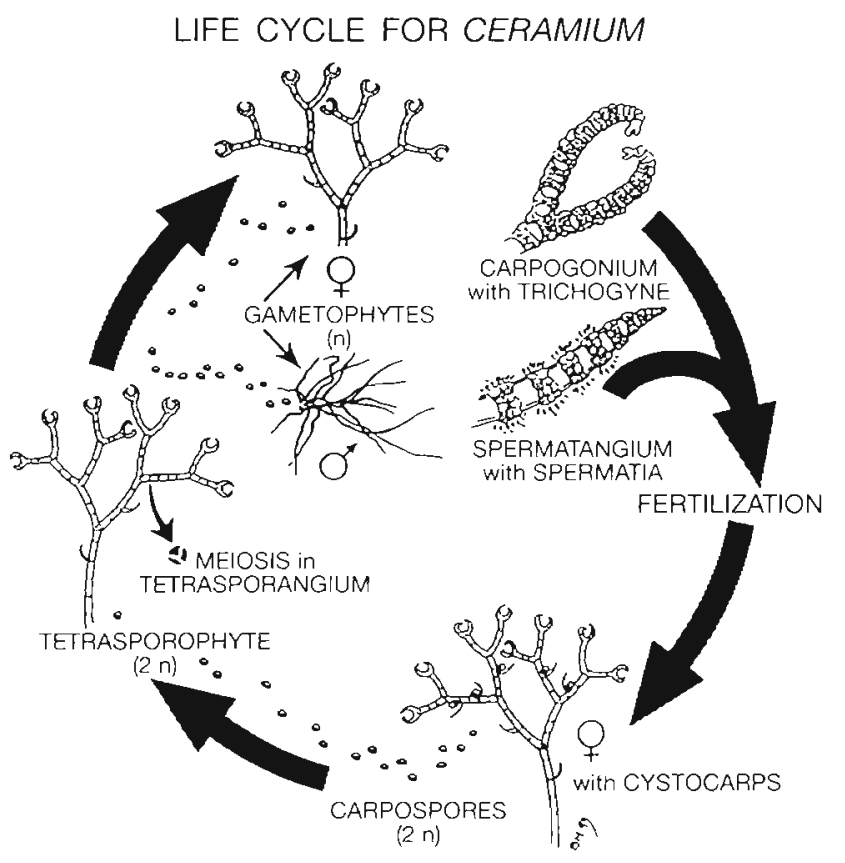

Fig. 1. Life cycle of the genus Ceramium

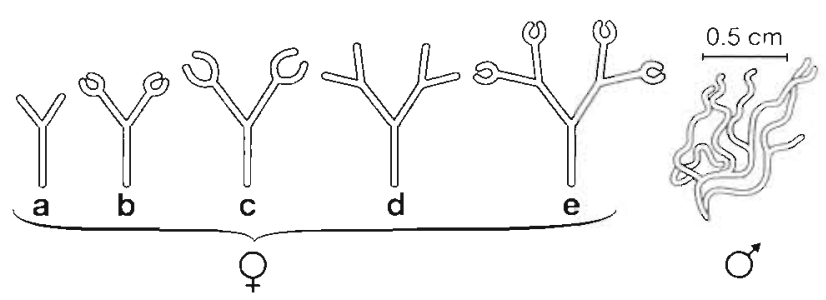

Fig. 2. Ceramium strictum. The figure shows the continuous growth development of the female gametophyte. As the plant grows, new claws are produced at the tips. Growth from stage ' $b$ ' to stage ' $e$ ' takes $3 \mathrm{~d}$ in natural seawater at $23^{\circ} \mathrm{C}$ and a light intensity of $35 \mu \mathrm{mol} \mathrm{s}{ }^{-1} \mathrm{~m}^{-2}$ Size of the male gametophyte at the start of a test also shown

(Figs. 1 \& 2). The reproductive organs, i.e. carpogonium, on the female plant develop on the outside of the 'claws' at/near the tips (Fig. 1). The genus Ceramium grows mainly by apical growth. Cells that develop into carpogonium are only receptive as long as they are on the claws. Once the carpogonial cells are below the 'claw' (compare Fig. 2b and e), they have lost their reproductive capacity (author's pers. obs.). The male plants produce spermatia from spermatangia formed within the cortical cells of older parts of the plant (Fig. 1).

Natural seawater $(20 \%)$, enriched with nitrate $\left(3460 \mu \mathrm{g} \mathrm{l}^{-1}\right)$, phosphate $\left(878 \mu \mathrm{g} \mathrm{l^{-1 }}\right)$, vitamins and trace elements, was used throughout the experiments (Eklund 1993, 1995). Natural seawater was collected at $40 \mathrm{~m}$ depth from an uncontaminated site on the Swedish west coast, i.e. Kristineberg Marine Biological Station. The growth, fertilisation and cystocarp development took place at $22 \pm 2^{\circ} \mathrm{C}$ using a light intensity of $35 \pm 12 \mu \mathrm{mol} \mathrm{m} \mathrm{m}^{-2} \mathrm{~s}^{-1}$ and a light:dark regime of $16: 8 \mathrm{~h}$. In each dose-response experiment, 10 to 13 concentrations of phenol were used with 5 replicates for each concentration. During fertilisation, male and female plants were paired for a $24 \mathrm{~h}$ period. Afterwards, the female plants were transferred to new media. Over the following $6 \mathrm{~d}$, successful fertilisation resulted in the growth and maturation of cystocarps (Fig. 1). Cystocarps present $6 \mathrm{~d}$ after fertilisation were counted using a stereo microscope. This was used as an endpoint in all experiments. The concentration which caused a $50 \%$ decrease in the number of cystocarps compared to the control was determined, i.e. $\mathrm{EC}_{50}$ value. Calculations were carried out using linear interpolation in the ToxCalc 5 software program (Anonymous 1994).

Effect of phenol on development of reproductive organs. To investigate the effect of phenol on the development of reproductive organs from the gametophyte cells, male and female plants were grown separately in different concentrations of phenol, $3 \mathrm{~d}$ prior to fertilisation. Female plants as shown by ' $b$ ' in Fig. 2 
and a $0.5 \mathrm{~cm}$ large male bush were used at the start of exposure. After $3 \mathrm{~d}$ growth in phenol the female plants had reached a stage roughly similar to ' $e$ ' in Fig. 2 . The development of new carpogonium on the top claws should have occurred during the exposure to phenol. Cross fertilisations were then set up, i.e, male plants exposed to phenol $\times$ unexposed female plants, female plants exposed to phenol $\times$ unexposed male plants, female plants exposed to phenol $\times$ male plants exposed to phenol and controls of unexposed males $x$ unexposed females. The fertilisation period and subsequent growth phase of the female gametophytes took place in natural seawater without the addition of phenol. The effect upon the reproductive organs was measured as the reduction in fecundity in terms of the number of cystocarps produced.

Effect of phenol on fertilisation and maturation of cystocarps. The effect of phenol on the ability to conceive and the development of cystocarps was studied in 2 experiments. Fertilisation took place in phenol in both experiments. In one experiment the $6 \mathrm{~d}$ period of growth and maturation of the cystocarps occurred in phenol, whilst in the other the growth and maturation phase proceeded in the absence of phenol. The endpoint used was the number of cystocarps produced.

Effect of phenol on the whole reproduction process. Male and female gametophytes were exposed separately to phenol for $3 \mathrm{~d}$ prior to fertilisation and the same cross combinations as above were used. To cover the whole reproduction process, different concentra- tions of phenol were used for both the fertilisation period of $24 \mathrm{~h}$ and the growth period of $6 \mathrm{~d}$.

Effect of phenol on growth pattern. The experiments investigated 3 different exposure periods to phenol. The morphological appearance and the growth pattern of the female gametophytes were studied after exposure for $24 \mathrm{~h}$, for $3 \mathrm{~d}$ and for $10 \mathrm{~d}$. In the first series, phenol was only used during the 24 h fertilisation period. In the second series, females were exposed $3 \mathrm{~d}$ prior to fertilisation, while fertilisation and the $6 \mathrm{~d}$ growth period took place in clean water. In the third series the females were grown in phenol for $3 \mathrm{~d}$ prior to fertilisation, during the $24 \mathrm{~h}$ fertilisation period and over the following $6 \mathrm{~d}$ whilst the cystocarps matured. In all cases, the morphological appearance was observed after the sixth day of maturation of the cystocarps.

\section{RESULTS}

All investigated stages in the life cycle of Ceramium strictum were to some extent affected by phenol.

\section{Effect of phenol on reproductive organs}

When the male plants were exposed to different concentrations of phenol, prior to fertilisation, an effect was seen at concentrations of more than $60 \mathrm{mg}$ phenol $\mathrm{l}^{-1}$ (Fig. 3). The $\mathrm{EC}_{50}$ was determined to be $100 \mathrm{mg}$

Table 1. Ceramium strictum. Impact of phenol on different reproductive stages of the red alga. EC $\mathrm{C}_{\text {so }}$ is calculated on the number of cystocarps produced in each concentration of phenol. First set of data corresponds to Fig. 3 , the second to Fig. 4 and the third to Fig. 5

\begin{tabular}{|c|c|c|c|c|c|}
\hline Sex & $\begin{array}{c}\text { Growth of gametophytic } \\
\text { plants prior to fertilisation } \\
( \pm \text { phenol for } 3 \text { d) }\end{array}$ & $\begin{array}{l}\text { Fertilisation } \\
\qquad(24 \mathrm{~h})\end{array}$ & $\begin{array}{l}\text { Growth of } \\
\text { cystocarp } \\
\text { (6 d) }\end{array}$ & $\begin{array}{c}E_{50} \\
\left.(\mathrm{mg} \text { phenol }]^{-1}\right)\end{array}$ & $\begin{array}{l}95 \% \\
\text { confidence } \\
\text { limits }\end{array}$ \\
\hline \multicolumn{6}{|c|}{ Effect on reproductive organs of gametophytes } \\
\hline Male & + & & & & \\
\hline Female & - & - & - & 100 & $(76-114)$ \\
\hline Male & - & & & & \\
\hline Female & + & - & - & 6.1 & $(4.8-7.5)$ \\
\hline Male & + & & & & \\
\hline Female & + & - & - & 5.4 & $(4.1-7.1)$ \\
\hline \multicolumn{6}{|c|}{ Effect on fertilisation and maturation of cystocarps } \\
\hline Male & - & & & & \\
\hline Female & - & + & - & 59 & $(53-66)$ \\
\hline Male & - & & & & \\
\hline Female & - & + & + & 39 & $(36-43)$ \\
\hline \multicolumn{6}{|c|}{ Effect on whole reproduction process } \\
\hline Male & + & & & & \\
\hline Female & - & + & + & 28 & $(21-45)$ \\
\hline Male & - & & & & \\
\hline Female & + & + & + & 5 & $(4.2-6.4)$ \\
\hline Male & + & & & & \\
\hline Female & + & + & + & 6.9 & $(4.0-9.6)$ \\
\hline
\end{tabular}




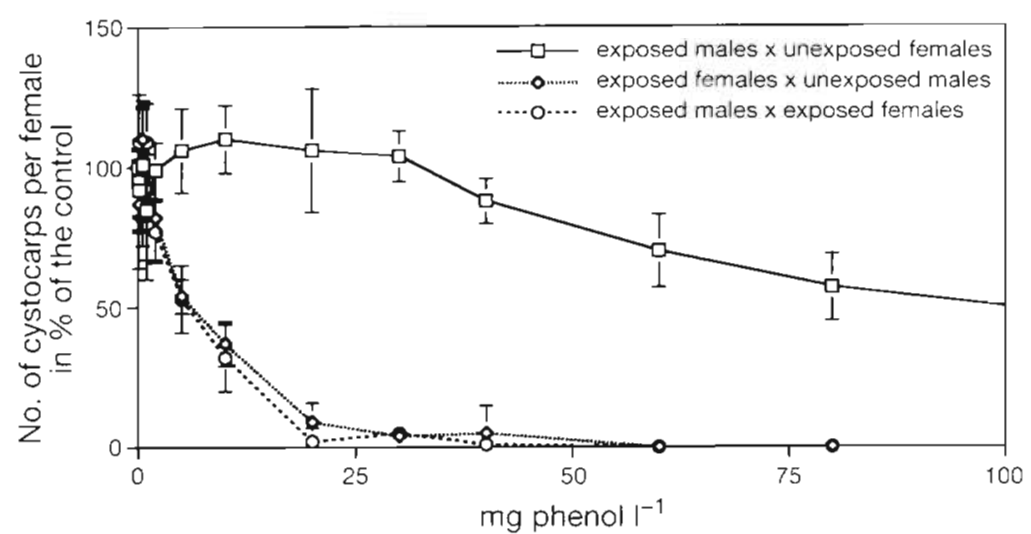

Fig. 3. Ceramium strictum. Effect of phenol on the reproductive organs of gametophytes. Exposure to phenol was for $3 \mathrm{~d}$ prior to fertilisation. Fertilisation (24 h) and maturation of cystocarps ( $6 \mathrm{~d}$ ) occurred in clean water, after which the cystocarps were counted. Error bars show $95 \%$ confidence limits

\section{Effect of phenol on the whole reproduction process}

A comparison of the curves in Figs. 3 $\& 5$ shows that when the female gametophytes were pre-exposed to phenol. the responses are very similar. The $E_{50}$ values lie between 5 and $7 \mathrm{mg}$ phenol $1^{-1}$ for all 4 experiments and the confidence limits show that no significant differences exist (Table 1). The effect was about 5 times less $\left(\mathrm{EC}_{50}\right.$ at $28 \mathrm{mg} \mathrm{l}^{-1}$ ) when fertilisation and maturation of the cystocarps took place in phenol and only the male plants had been exposed prior to fertilisation (Table 1, Fig. 5). phenol $1^{-1}$ (Table 1). At the highest tested concentration, i.e. $200 \mathrm{mg} \mathrm{l}^{-1}$, the male plants still had a fertilisation capacity of about $14 \%$ compared to the control. The effect was much more severe when the females were exposed prior to fertilisation. At concentrations less than $2 \mathrm{mg} \mathrm{l}^{-1}$, reproductive capacity was around $80 \%$ but already at $20 \mathrm{mg} \mathrm{l}^{-1}$ it had diminished to only $8 \%$ (Fig. 3). At a concentration of $6.1 \mathrm{mg} \mathrm{l}^{-1}$ the reproduction capacity was $50 \%$ of the control (Table 1). A similar response curve can be observed when both male and female plants were exposed to phenol prior to fertilisation and the $\mathrm{EC}_{50}$ was determined to $5 \mathrm{mg} \mathrm{l}^{-1}$ (Table 1, Fig. 3).

\section{Effect of phenol on fertilisation and maturation of cystocarps}

The effect was not as drastic when phenol was present only during the $24 \mathrm{~h}$ fertilisation period and ripening of cystocarps took place in clean water. The $\mathrm{EC}_{50}$ was determined to be $59 \mathrm{mg}$ phenol $\mathrm{l}^{-1}$ (Table 1, Fig, 4), which is about 12 times less than when the female gametophytes were exposed prior to fertilisation. The number of cystocarps was reduced by about another third when the maturation of the cystocarps also took place in phenol. Thus, the $\mathrm{EC}_{50}$ was in this case determined to be $39 \mathrm{mg}$ phenol $\mathrm{l}^{-1}$ (Table 1, Fig. 4).

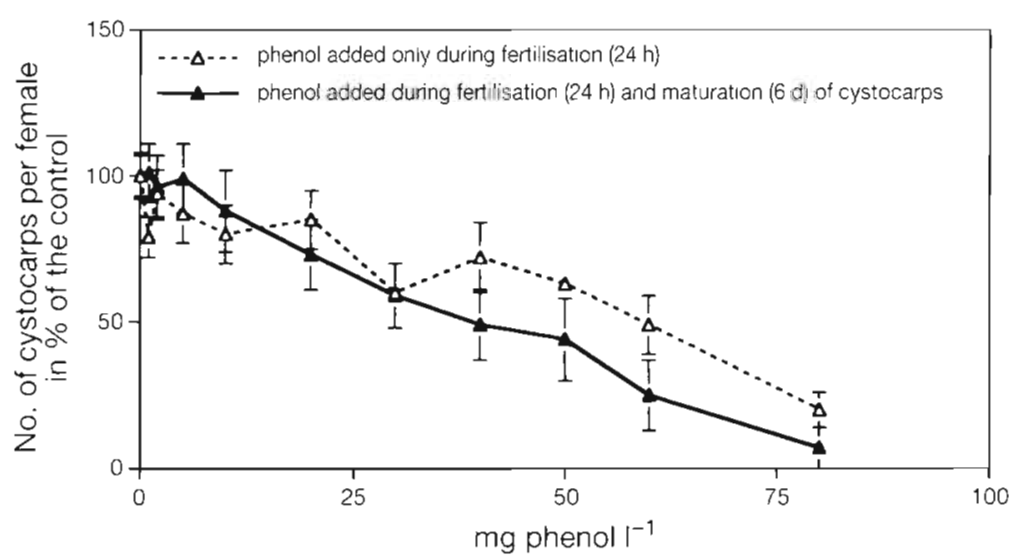

Fig. 4. Ceramium strictum. Effect of phenol on the fertilisation and maturation of cystocarps. Cystocarps were counted after the $6 \mathrm{~d}$ maturation period. Error bars show $95 \%$ confidence limits

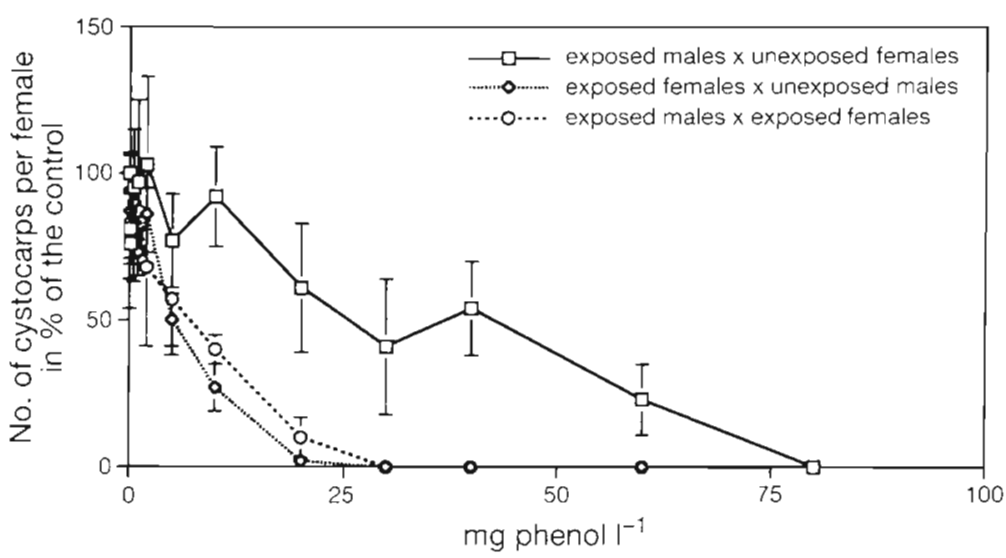

Fig. 5. Ceramium strictum. Effect of phenol on reproduction (development of reproductive organs, fertilisation and maturation of cystocarps are included). Gametophytic males and females were exposed separately to different concentrations of phenol $3 \mathrm{~d}$ prior to fertilisation. Fertilisation $(24 \mathrm{~h})$ and the maturation of cystocarps also took place in phenol. Cystocarps were counted after $6 \mathrm{~d}$ of maturation. Error bars show $95 \%$ confidence limits 


\section{Effect of phenol on growth pattern}

In the 3 investigations of exposure period to phenol, marked morphological growth patterns were observed in the female gametophytic plants. The normal pattern for a female gametophyte is an even, dichotomous growth with few lateral branches. When the lateral branches form, they are subordinate to the apical growth, and thus develop very slowly. When fertilisation occurs in a healthy plant, cystocarps develop and apical growth continues (Fig. 6; concentration 0). In series A. (Fig. 6), the female gametophytes were only exposed to phenol during the $24 \mathrm{~h}$ period of fertilisation. The following $6 \mathrm{~d}$ of growth occurred in clean water. The results show that growth was normal up to a concentration of $20 \mathrm{mg}$ phenol $\mathrm{l}^{-1}$. At this concentration, a reduced apical growth was observed. Growth came to a halt at many tips after the onset of the cystocarp. At $60 \mathrm{mg}$ phenol $\mathrm{l}^{-1}$ this appearance was the rule. All cystocarps were situated at the tips and were comparatively small. No apical growth occurred above them. At $80 \mathrm{mg}$ phenol $\mathrm{l}^{-1}$, the female plants showed little or no growth and the tips had a compact appearance, consisting of very small cells (Fig. 6, series A). In
A
B
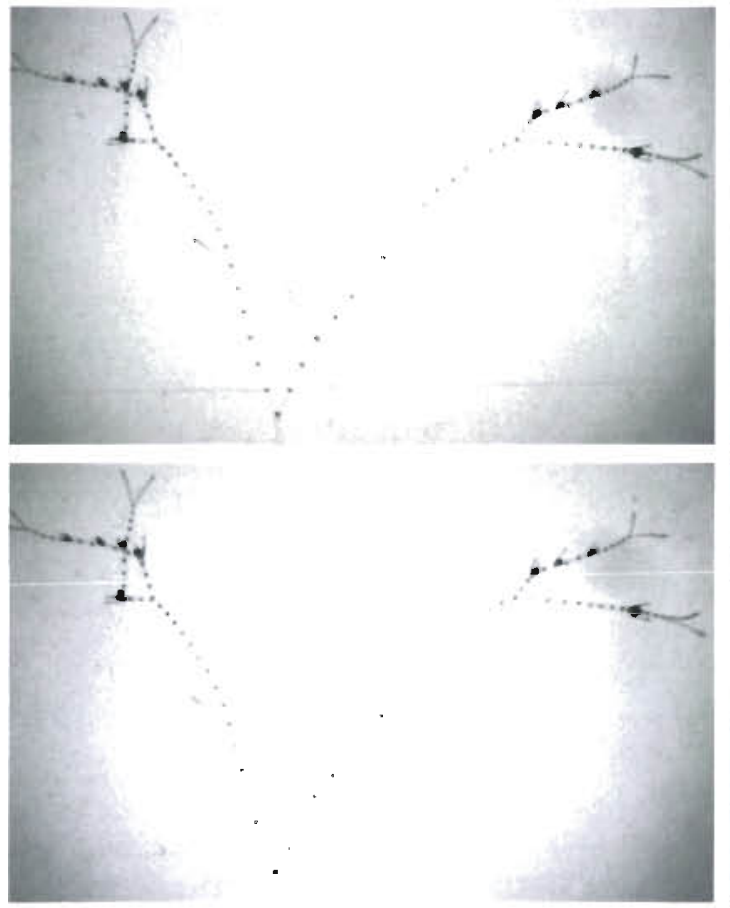

C

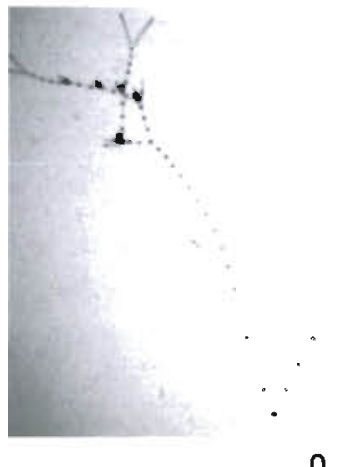

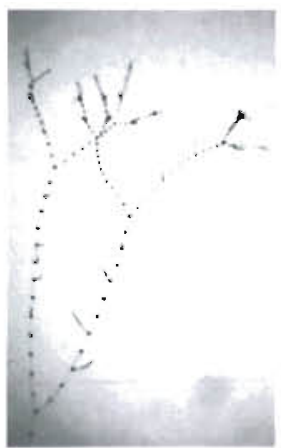
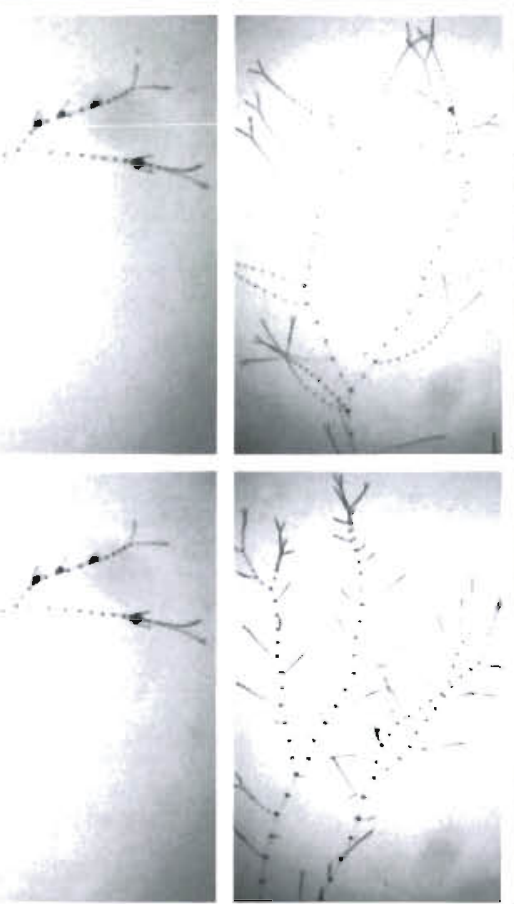

20
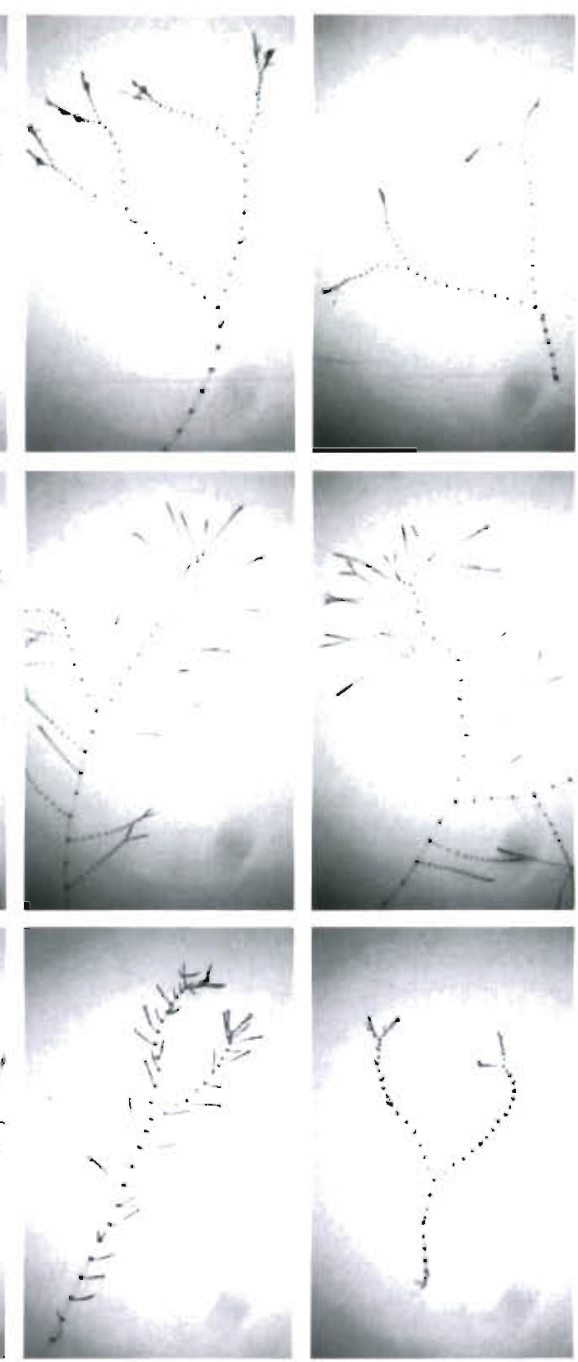

40

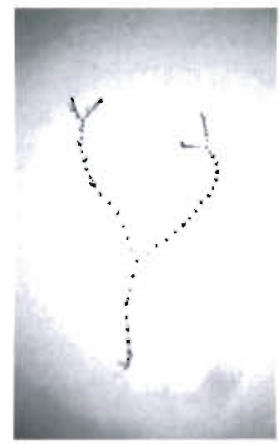

80

mg phenol I-1

Fig. 6. Ceramium strictum. Effect on growth response of female gametophytic plants when exposed to phenol for different lengths of time. Pictures show the typical appearance of the female plants $6 \mathrm{~d}$ after fertilisation has occurred. Series A: $24 \mathrm{~h}$ of exposure to phenol during the fertilisation period, followed by $6 \mathrm{~d}$ of maturation in clean water. Series $\mathrm{B}$ : $3 \mathrm{~d}$ of exposure to phenol prior to fertilisation. Fertilisation $(24 \mathrm{~h})$ and maturation of cystocarps (6 d) occurred in clean water Series C: $10 \mathrm{~d}$ exposure to phenol, i.e. $3 \mathrm{~d}$ prior to fertilisation, $24 \mathrm{~h}$ during fertilisation and $6 \mathrm{~d}$ of growth after fertilisation 
series B (Fig. 6) plants were grown for $3 \mathrm{~d}$ in phenol, followed by fertilisation for $1 \mathrm{~d}$ and a $6 \mathrm{~d}$ growth period in clean water. With increasing concentration of phenol above $20 \mathrm{mg}$ phenol $\mathrm{l}^{-1}$, a steady increase in the number of lateral branches was produced. At $40 \mathrm{mg}$ phenol $\mathrm{l}^{-1}$ and higher, almost each cell had developed a new branch. The apical dominance of the original plant had disappeared and instead, the apical cells of the lateral side branches had taken over, giving a much more bushy appearance to the alga.

When the female gametophytes were grown in the presence of phenol for $10 \mathrm{~d}$ (Fig. 6, series C), all plants at concentrations from $10 \mathrm{mg}$ phenol $\mathrm{l}^{-1}$ and above showed distinct changes in growth pattern. A greater number of lateral branches was observed, and overall growth became increasingly reduced at higher concentrations of phenol. At $40 \mathrm{mg}$ phenol $\mathrm{l}^{-1}$, almost every cell had developed a new lateral branch. This pattern was even more apparent as concentrations increased, and at the highest tested concentrations the plants looked like small juniper bushes (Fig. 6, series C). The few cystocarps found in concentrations greater than $20 \mathrm{mg}$ phenol $\mathrm{l}^{-1}$ were small and located near the tips. No apical growth occurred.

\section{DISCUSSION}

\section{Effect of phenol on reproductive stages}

The effect of phenol on the reproductive functioning of the male plants was much less than that observed in the female plants. When phenol exposure took place prior to fertilisation, a $50 \%$ effect was first seen at concentrations about 20 times higher than in the female plant, i.e. 100 compared to $5-7 \mathrm{mg}$ phenol $1^{-1}$ (Table 1, Fig. 3). Even when the spermatangia are affected by phenol, they seem to quickly resume their ability to produce new spermatia once transferred to clean surroundings. The spermatangium of the Ceramium genus repeatedly proliferates spermatia. Older spermatia are released as young spermatia expand to take their place (Kugrens 1980). In the differentiation of spermatia 1 or 2 massive, mucilagecontaining vesicles are formed (Fetter \& Neushul 1981, Broadwater \& Scott 1983). As the spermatia are released, discharge of the spermatial vesicles occurs (Scott \& Dixon 1973, Kugrens 1980). This discharge of mucilage may serve to dilute the phenol and thus reduces the toxic effect. Also, the mother (father) cells within the spermatangium may yield some physical protection to the outer layers of released spermatia. A combination of these factors may explain the rapid resumption of the ability of male gametophytes to produce fresh viable spermatia.
In all experiments in which the female gametophytes were exposed prior to fertilisation, a $50 \%$ reduction in reproductive performance was observed at 5 to $7 \mathrm{mg}$ phenol $\mathrm{l}^{-1}$. The response of the exposed female gametophytes is almost identical in Figs. $3 \& 5$. Since the toxic effect does not increase in the experiments shown in Fig. 5 in which fertilisation and the maturation period of cystocarps had taken place in phenol, it can be concluded that it is the formation of the female carpogonium that is most seriously affected. A comparison of these results also suggests that no recovery in the reproductive capacity had occurred during the $24 \mathrm{~h}$ fertilisation period in clean water (Fig. 3). The recovery time for the reproductive capacity of the female gametophytes was not investigated further in this study. However, since it takes about $3 \mathrm{~d}$ for a new pair of claws to form (Eklund unpubl.), this is probably the least amount of time required for the female plant to resume its normal reproductive capacity. The history of the gametophytic female plant seems to be very important, and the exposure of plants prior to fertilisation was found to be decisive to the outcome of reproduction. Ceramium strictum is a monoserial alga, which means that each cell is in direct contact with the surrounding water. As phenol has a high solubility in water, all cells are likely to be affected by the toxicant. In Florideophyceae, carpogonia, spermatangia, monosporangia, carposporangia, and tetrasporangia are all produced by transformation of the apical initials (Gabrielson \& Garbary 1986). Based on the results from this investigation, it is evident that phenol passes through the plant membrane and interferes either directly on the apical cell or somewhere in the complex processes occurring within the cell during the formation of carpogonia and trichogynes.

When the fertilisation period of $24 \mathrm{~h}$ occurred in phenol, the number of cystocarps increased 10-fold compared to when the entire experiment had taken place in phenol (Table 1, EC 50 of $59 \mathrm{mg}$ phenol $\mathrm{l}^{-3}$; and Table $1, \mathrm{EC}_{50}$ of 5 to $7 \mathrm{mg}$ phenol $\mathrm{l}^{-1}$ ). The cells which develop into carpogonia form close to the tip of the claw, initiated by the apical cell (Gabrielson \& Garbary 1986). Up to 8 cells may mature into reproductive organs, i.e. carpogonia with 4 trichogynes on each side of the 'claw' (author's pers. obs; see also Fig. 6 concentration 0 ). As the growth of the female gametophyte from ' $b$ ' to ' $e$ ', as shown in Fig. 2, takes $3 \mathrm{~d}$ (Eklund unpubl.), about one-third of the carpogonia can be expected to form during the fertilisation period of $24 \mathrm{~h}$. This is supported by findings reported by Eklund (1993) where the number of cystocarps increased by one-third when the fertilisation period was extended from 1 to $2 \mathrm{~d}$. The toxic effect increased by about a third when the male gametophytes were exposed to phenol prior to fertilisation compared with when fertilisation had taken place in phenol (Table 1, $\mathrm{EC}_{50}$ of 
$59 \mathrm{mg}$ phenol $\mathrm{l}^{-1}$; and Table $1, \mathrm{EC}_{50}$ of $100 \mathrm{mg}$ phenol $\left.\mathrm{l}^{-1}\right)$. These results suggest that the main impact of phenol is on the female gametophyte during the $24 \mathrm{~h}$ fertilisation period. Phenol most likely affects the apical cells, which lose their ability to initiate carpogonia. This means that only the ripe carpogonia that exist before exposure to phenol can become fertilised. This explains the reduction in the number of cystocarps. The results also imply that ripe carpogonia have a higher resistance to phenol than less ripe ones (compare the discussion on growth pattern below).

The effect of phenol on the maturation stage of the cystocarps is not as severe as on the development of reproductive organs. This can be observed by comparing the results from experiments in which only fertilisation had taken place in the presence of phenol to those in which both fertilisation and the maturation of cystocarps had occurred in phenol (Table 1, EC 50 of 59 and $39 \mathrm{mg}$ phenol $\mathrm{l}^{-1}$, respectively). A slight decrease in the reproductive capacity indicates that the maturation of cystocarps is to some extent affected by phenol. Thus, fertilisation may take place but the development of the cystocarp is disturbed. This is supported by observations made during this study where supporting branches to a cystocarp developed, but the cystocarp never appeared. The maturation of the cystocarp seems to have been interrupted. Normally, once fertilisation has occurred, adjacent cells of the gametophyte become involved and take part in nutrient support to the cystocarp and the production of carpospores (Hommersand \& Fredericq 1990). Phenol may interact in some or several of the steps involved in the development of the cystocarp and carpospore production.

Studies similar to this one using phenol have been carried out for $\mathrm{Cu}, \mathrm{Zn}, \mathrm{Hg}, \mathrm{Cd}$, and chlorate (Eklund unpubl.). All show the same tendencies as were observed in the phenol experiments, i.e. that the female gametophyte is the most vulnerable of the investigated stages.

\section{Effect of phenol on growth}

Marked changes were observed in the morphological appearance of the female plants for the 3 different procedures used in this study. It is clear that the higher the concentration of phenol, the more growth is reduced (Fig. 6, series $A$ and $C$ ). In the first procedure, i.e. series $\mathrm{A}$, exposure to phenol had occurred for $24 \mathrm{~h}$, after which the plants were transferred to fresh media. Even after $6 \mathrm{~d}$, the growth of the plants that had been pre-exposed to 80 phenol $\mathrm{mg} \mathrm{l}^{-1}$ was significantly retarded (Fig. 6, series A). This suggests that a pulse of a toxicant may affect growth for longer than the actual exposure time. As plant growth continues in phenol, as shown in Fig. 6 series $C$, the striking response is the increased number of side branches. It is clear that phenol not only retards growth, but also affects the dominance of the apical cell. This is illustrated by series $B$ in Fig. 6 when exposure to phenol had taken place only before fertilisation. Harmful concentrations of phenol seem to reduce apical growth and to increase meristematic growth in each cell. The plant responds by sending out branches in different directions, and thus the likelihood of growth away from the harmful substance is increased. This behaviour also increases the number of tips where the female reproductive organs may develop, and the chances of reproduction consequently increase. Ceramium strictum female gametophytes adopt a bushier appearance under the influence of toxicants from different complex effluents (author's pers. obs.). This parameter could be used as an indicator of stress in the environment.

In the process of a normal fertilisation in the genus Ceramium, cells adjacent to the carpogonial cell support the growth of the cystocarps (Hommersand \& Fredericq 1990). Since much effort is put into the support of the cystocarps and production of carpospores, the overall length of the plant is reduced. Normally the plant continues its dichotomous growth above the formed cystocarps (Fig. 6, concentration 0). Series A in Fig. 6 shows that even when growth is much reduced, cystocarps still develop. At $60 \mathrm{mg}$ phenol $\mathrm{l}^{-1}$, the few cystocarps found were all situated on the very tip of the claw. The plants seem to prioritise the production of cystocarps and carpospores. Personal observations indicated that the first carpogonia to develop on each claw are often the largest and healthiest looking cystocarp. This is also the case for many other plants, where considerable effort is put into the first bud and less into subsequent ones (Silvertown \& Lowett Doust 1993 and references therein). This may also mean that the first carpogonia produced on each claw have a better ability to resist phenol than the younger ones closer to the tip.

\section{CONCLUSIONS}

The development of reproductive organs on female and male gametophytes were affected by phenol. The formation of female reproductive organs was about 20 times more sensitive than the reproductive functioning of male spermatangia. A $50 \%$ decrease in reproduction capacity was seen at 5 to $7 \mathrm{mg}$ phenol $\mathrm{l}^{-1}$ when the female gametophytes were exposed prior to fertilisation and the corresponding figure for the male plants was $100 \mathrm{mg}$ phenol $\mathrm{l}^{-1}$.

No recovery of the female plant was seen after $24 \mathrm{~h}$.

The gametophytic female plant is the most vulnerable life stage of the ones studied and its history 
was found to be decisive in the outcome of reproduction.

Maturation of cystocarps was affected by phenol. The number of cystocarps produced decreased by about $20 \%$ compared to maturation in clean water.

Phenol affected the growth pattern of the female gametophytes. The higher the concentration of phenol, the more pronounced the loss of apical dominance. Instead of normal dichotomous growth, each cell initiated a lateral side branch giving the plant a more bushy appearance.

A pulse exposure of phenol of more than $60 \mathrm{mg} \mathrm{I}^{-1}$ influenced the growth of the female gametophyte by as much as $1 \mathrm{wk}$.

Acknowledgement. This study was financially supported by the Swedish Environmental Protection Agency. Comments on the manuscript, especially by Lena Kautsky, are greatly appreciated

\section{LITERATURE CITED}

Andersson S, Kautsky L (1996) Copper effects on reproductive stages of Baltic Sea Fucus vesiculosus. Mar Biol 125:171-176

Anonymous (1992) Microbics manual. A toxicity testing handbook 1-V. Microbics Corporation, Carlsbad, CA

Anonymous (1994) Tidepool Scientific Software ToxCalc, Ver 5.0, Comprehensive toxicity data analysis and database software. Tidepool Scientific Software, McKinleyville, CA

Broadwater ST, Scott J (1983) Ultrastucture ofearly development in the female reproductive system of Polysiphonia harveyi Bailey (Ceramiales, Rhodophyta). J Phycol 18:427-441

Editorial responsibility: Otto Kinne (Editor),

Oldendorf/Luhe, Germany
Eklund B (1993) A 7-day reproduction test with the marine red alga Ceramium strictum. In: Slooff W, de Kruijf $\mathrm{H}$ (eds) The science of the total environment, Suppl, Part 1 Proc 2nd Eur Conf on Ecotoxicology. Elsevier Science Publishers BV, Amsterdam, p 749-759

Eklund B (1995) Manual for the reproduction test using the marine red alga Ceramium strictum. ITM Report Series No. 41 Institute of Applied Environmental Research (ITM), Stockholm University, p 1-16

Fetter R, Neushal M (1981) Studies on developing and released spermatia in the red alga Tiffaniella snyderae (Rhodophyta). J Phycol 17:141-159

Gabrielson PW, Garbary DJ (1986) Systematics of red algae (Rhodophyta). CRC Crit Rev Plant Sci 3(4):329-366

Hommersand MH, Fredericq S (1990) Sexual reproduction and cystocarp development. In: Cole KM, Sheath RG (eds) Biology of the red algae. Cambridge University Press, Cambridge, $\mathrm{p}$ 305-346

Hopkin R, Kain JM (1978) The effects of some pollutants on the survival, growth and respiration of Laminaria hyperboria. Estuar Coast Mar Sci 7:531-553

Kugrens P (1980) Electron microscopic observations on the differentiation and release of spermatia in the marine red alga Polysiphonia hendryi (Ceramiales, Rhodomelaceae) Am J Bot 67:519-528

Maggs CA, Hommersand M (1993) Seaweeds of the British Isles, Vol 1, Rhodophyta, Part 3A, Ceramiales. HMSO, London

Scott JL, Dixon PS (1973) Ultrastructure of spermatium liberation in the marine red alga Ptilota densa. J Phycol 9 $85-91$

Silvertown JW, Doust JL (1993) Introduction to plant population biology. Blackwell Scientific Publications, London

Thursby GB, Steele RL, Kane ME (1985) Effect of organic chemicals on growth and reproduction in the marine red alga Champia parvula. Environ Toxicol Chem 5: 1013-1018

Submitted: December 29, 1997; Accepted: April 6, 1998

Proofs received from author(s): May 28, 1998 